\title{
Financial Problems Met by Schools in the Onslaught of COVID 19: Implications to Fiscal Management of Learning Institutions
}

\author{
ZAITUNA KHAMIDULLINA ${ }^{1}$, JOEL ALANYA-BELTRAN² ${ }^{2}$, KANNAPAT KANKAEW ${ }^{3}$, \\ HARSANDALDEEP KAUR ${ }^{4}$, ALFE M. SOLINA ${ }^{5}$, GEENA HIPOLITO-PINGOL ${ }^{6}$, \\ GILBERT C. MAGULOD JR ${ }^{7}$, JOSEPH JEAN SINCHITULLO GÓMEZ ${ }^{8}$, P. JUSTIN SUDHAKAR ${ }^{9}$, \\ ASSEL KHASSENOVA ${ }^{10}$, SUPAT CHUPRADIT ${ }^{11}$ \\ ${ }^{1}$ Astana Medical University Kazakhstan. https://orcid.org/0000-0002-0902-5269 \\ Universidad Tecnológica del Perú, Peru, c18121@utp.edu.pe, https://orcid.org/0000-0002-8058-6229 \\ ${ }^{3}$ Suan Sunandha Rajabhat University, Thailand, email: kunnapat.ka@ssru.ac.th \\ ${ }^{4}$ University School of Financial Studies, Guru Nanak Dev University, India, email:harsandal.usfs@gndu.ac.in \\ ${ }^{5}$ Cavite State University Imus Campus, Imus City, Cavite, Philippines \\ 6Pampanga State Agricultural University, Philippines, email: geena_hipolito@psau.edu.ph \\ ${ }^{7}$ Cagayan State University, Philippines, email: gilbertmagulod_rdecsulasam28@yahoo.com \\ ${ }^{8}$ Universidad Nacional de Ingeniería, Peru, email: jsinchitullog@uni.edu.pe \\ ${ }^{9}$ Department of Education Planning and Management College of Education and Behavioural Studies Jigjiga \\ University, Somali Region. Ethiopian \\ ${ }^{1-A s t a n a}$ Medical University, Kazakhstan https://orcid.org/0000-0002-2328-6924 \\ ${ }^{11}$ Chiang Mai University, Thailand https://orcid.org/0000-0002-8596-2991
}

\begin{abstract}
The covid-19 infection has reduced educational institutions' economic aspects and made it possible for the researchers to assess the financial issues associated with funding and efficiency of operations among schools in South East Asian universities. In the realm of education, economic concerns are not the central role of the holder, but actors who properly define educational achievement to conduct all training establishments and activities. The essential components are lifelong training and dedication, competency, managerial skills, and instructors in all educational facilities. The study employed descriptive qualitative and literature review to secondary sources. The primary findings were that, because of the COVID 19 issue, school finances are often challenging to manage on a macro and micro level. Consequently, schools are forced to seek the most efficient allocation of money in the COVID 19 era. This study presents implications for the Fiscal Management of Learning Institutions.
\end{abstract}

Keywords: Covid 19; Funding; Operations; Efficiency; Economy; Financial problems.

JEL Classification: E60, E62, G00

Received: June 17, 2021

Accepted: October 03, 2021 


\title{
Problemas Financieros de las Escuelas en la Embestida de la COVID 19: Implicaciones para la Gestión Fiscal de las Instituciones Educativas
}

\author{
ZAITUNA KHAMIDULLINA ${ }^{1}$, JOEL ALANYA-BELTRAN², KANNAPAT KANKAEW ${ }^{3}$, \\ HARSANDALDEEP KAUR ${ }^{4}$, ALFE M. SOLINA ${ }^{5}$, GEENA HIPOLITO-PINGOL ${ }^{6}$, \\ GILBERT C. MAGULOD JR ${ }^{7}$, JOSEPH JEAN SINCHITULLO GÓMEZ ${ }^{8}$, P. JUSTIN SUDHAKAR ${ }^{9}$, \\ ASSEL KHASSENOVA ${ }^{10}$, SUPAT CHUPRADIT ${ }^{11}$ \\ ${ }^{1}$ Astana Medical University Kazakhstan. https://orcid.org/0000-0002-0902-5269 \\ ${ }^{2}$ Universidad Tecnológica del Perú, Peru, c18121@utp.edu.pe, https://orcid.org/0000-0002-8058-6229 \\ ${ }^{3}$ Suan Sunandha Rajabhat University, Thailand, email: kunnapat.ka@ssru.ac.th \\ ${ }^{4}$ University School of Financial Studies, Guru Nanak Dev University, India, email:harsandal.usfs@gndu.ac.in \\ ${ }^{5}$ Cavite State University Imus Campus, Imus City, Cavite, Philippines \\ ${ }^{6}$ Pampanga State Agricultural University, Philippines, email: geena_hipolito@psau.edu.ph \\ ${ }^{7}$ Cagayan State University, Philippines, email: gilbertmagulod_rdecsulasam28@yahoo.com \\ ${ }^{8}$ Universidad Nacional de Ingeniería, Peru, email: jsinchitullog@uni.edu.pe \\ ${ }^{9}$ Department of Education Planning and Management College of Education and Behavioural Studies Jigjiga \\ University, Somali Region. Ethiopian \\ ${ }^{1-A s t a n a ~ M e d i c a l ~ U n i v e r s i t y, ~ K a z a k h s t a n ~ h t t p s: / / o r c i d . o r g / 0000-0002-2328-6924 ~}$ \\ ${ }^{11}$ Chiang Mai University, Thailand https://orcid.org/0000-0002-8596-2991
}

\begin{abstract}
RESUMEN
La infección de covid-19 ha reducido los aspectos económicos de las instituciones educativas y ha hecho posible que los investigadores evalúen las cuestiones financieras relacionadas con la financiación y la eficiencia de las operaciones entre las escuelas de las universidades del sudeste asiático. En el ámbito de la educación, las preocupaciones económicas no son el papel central del titular, sino los actores que definen adecuadamente los logros educativos para llevar a cabo todos los establecimientos y actividades de formación. Los componentes esenciales son la formación y la dedicación a lo largo de toda la vida, la competencia, la capacidad de gestión y los instructores en todos los centros educativos. En el estudio se empleó una revisión descriptiva cualitativa y bibliográfica de fuentes secundarias. Las principales conclusiones fueron que, debido a la cuestión de la COVID 19 , las finanzas escolares suelen ser difíciles de gestionar a nivel macro y micro. En consecuencia, las escuelas se ven obligadas a buscar la asignación más eficiente del dinero en la era del COVID 19. Este estudio presenta implicaciones para la gestión fiscal de las instituciones de enseñanza.
\end{abstract}

Palabras clave: Covid 19; Financiación; Operaciones; Eficiencia; Economía; Problemas financieros.

Clasificación JEL: E60, E62, G00 


\section{Introduction}

A COVID-19 pandemic is most likely to result in a significant economic shock since the 2008 financial crisis. Public health systems have a significant burden now due to the spread of COVID-19, and this burden will only increase as these systems struggle. Restrictions on the distribution of COVID-19 have led to a massive imbalance between supply and demand. Investing may become difficult due to trade disruptions, commodity price declines, and a tighter financial environment. Due to these impact events, it is anticipated that there will be a rise in unemployment and underemployment, which may endanger the survival of many companies across the globe.

It is a terrible catastrophe for the people of Earth when a new strain of COVID-19 emerges. Covid 19 epidemic has impacted every sector of human existence on Earth (Cohen, et al, 2020, Van Lancker \& Parolin, 2020, Ziauddeen, et al, 2020). Everyone was impacted by the most recent epidemic of Covid 19 except for the economy, health, and education (Viner, et al, 2020, Greenhawt, et al, 2020). Especially in Southeast Asian nations, many education systems throughout the globe have closed down because of the Covid 19 outbreak, beginning at the lowest level and continuing to the highest levels as well as having to remain open in order to stay operational (Chang, et al, 2021, Han, et al, 2020, Ng \& Or, 2020).

There are two different impacts from the COVID-19 epidemic: one has to do with the overall sustainability of schooling, and the other has to do with medical advancements in the area of diabetes. An immediate impact is felt by both Indonesian families and the country as a whole, both in the rural areas and major cities. Indonesian families that know their family members intimately choose to send their children to school at home. Most families do not expect their production levels to suffer when they opt to home school their children. Students who have been taught face-to-face may also have mental health problems (Ahmed, et al, 2020, Chang, et al, 2021, Roy, et al, 2020). Covid 19 is the most effective and complete kind of social education. Online education means that teaching happens. No previous instance has been found, and no scientific tests have been done.

Due to the limited availability of technological resources, all regions with an abnormally high concentration of school-age people and areas cut off from the rest of the country become oversaturated with tech (Djalante, et al, 2020). Obtaining money from one party to another is called financing, and whether you are getting it by yourself or through other institutions, that is what it is called (Nicola, Met al, 2020, Viner, et al, 2020). We learn via a combination of work and involvement, and this might be characterized as an effort in which schools invest in a requirement for the school's operations.

Despite constant rule revisions, the education economy is still a work in progress. Institutions that provide education are an alternative, and they charge tuition (Cauchemez, et al, 2009, Singh, et al, 2020, Yeasmin, et al, 2020). As fees increase, so does the strength of the institution due to this economic disaster (Cheng, et al, 2020, Tsurugano, et al, 2021). To provide for the ongoing financial needs of infrastructure and teacher welfare, a leader must formulate a finance strategy these days. The Covid 19 pandemic has prevented kids from engaging in school activities (Dereso, et al, 2020). How much of an impact does it have on the school's learning process? Asia has a plethora of studies demonstrating how educational institutions positively influence families' well-being (Inchley, et al, 2020, Lee \& Yoo, 2015, Rapoport, et al, 2020, Shek, 1997, Tsey, et al, 2010). When it comes to motivating and committing to an organization, a leader's ability to adjust and modify their style of leadership is just as important as it is for other positions in business. This means that leaders in education can be good leaders as long as they are able to make changes to their style when needed (Harris, 2020). A generally favorable influence on the financial and social well-being of families and the community is found for the Covid 19 pandemic, negatively affecting society. 4.0.

Most scientific discoveries include ideas and pieces of evidence (logical arguments, physical facts, etc.) found in organized discursive prose chunks. Research is backed up by data and analysis, with the concepts and evidence created to provide context and backdrop to the piece. The backdrop supports the goal by guiding us to the problem's formulation, which is then broken down into multiple parts. It 
is essential to have a suitable or strategy, and ultimately articulated in a conclusion for the goal outcomes to be in line with the objective technique. Literary research papers play a vital part in all of this. Therefore, paper research methods include search terms such as information retrieval, data retrieval, assessment, investigation, evaluation, examination, and analysis. Every essential element of the researcher's knowledge is documented in the methodology class (Netolicky, 2020).

\section{Methodology}

First, the writer decides on the topic or problem to be covered. Then, relevant research on the subject is identified and critically evaluated. Due to the literature that is already accessible, the sources for this paper provided further enrichment of literature as possible. The first stage for more in-depth data monitoring included analyzing findings from a collection of scientific papers and conferences. In order to research academic papers and hearings, categorizing all of the talks in the papers and proceedings into various categories is conducted. This concerns all of the problems that are relevant today.

In the meanwhile, interactive analysis is used to guarantee findings are as solid as feasible in relation to the components studied. With careful attention to detail, the tool NVivo aided with data analysis. unstructured and/or non-numeric data is gathered and Nvivo is intended for this purpose (Alam, 2020, Dalkin, et al, 2021). Categorizing, classifying, and organizing information; reviewing data connections; and integrating analysis with linking data between the methods in which patterns are discovered, analyzed, modeled, and shaped (Salahudin, et al, 2020).

Search engines and query tools may be used to search for patterns and cross-check information in many ways (Meanwell, 2021). Using the software's memo function, a user may make a collection of evidence to support their argument or project. Navis' software, which provides an array of research techniques, such as network and organizational analysis, action research, and evidence-based research, along with various discourse analysis methods, provides software for various research techniques, such as network and organizational analysis, as well as action research and evidence-based research (Al-Kindi \& Al-Khanjari, 2021). Users will be able to work with audio files, video, digital images, Microsoft Word, Microsoft Excel spreadsheets, rich text, plain text, and social networking data in NVivo (Castleberry, 2014).

\section{Results and Discussion}

\subsection{Funding Constraints Experienced by Schools in COVID 19}

Due to financial difficulties, many economic schools face an imminent economic foundation crisis. In Asia, we are in a state of multiple-dimensional disaster (Kang, et al, 2021, Al-Samarrai, Gangwar, \& Gala, 2020, Wang, et al, 2021). Even now, one may still see the effects of the post-coronavirus pandemic. Unmanaged educational institutions, who are ignorant of various assistance and guidance available, also impact the global education community. In order to maintain capacity to promote intellectual development, we must examine every facet of growth and sustainability at the institution (Dee \& Murphy, 2021, Knight, et al, 2021, Syverson, 2021). One of the United States' problems where a complete solution has not yet been found is the continuous financial access provided throughout the Coronavirus epidemic (Chevallier, 2021, Gutiérrez-Romero \& Ahamed, 2021). A large number of schools complain about their financial resources since their income is often insufficient to cover their expenses (Figueroa, et al, 2021, Gutiérrez-Romero \& Ahamed, 2021, Rajan, et al, 2021, Verguet, et al, 2021). Parents whose children have been out of work because of the Coronavirus pandemic feel the consequences of this, but so do those who have not yet found job due to the outbreak (Figueroa, et al, 2021).

In contrast to the above idea, the only difference between the two conceptions is who is responsible for supervising it. Privately funded education often includes financial support from students and/or parents (Bloch, et al, 2021, Wouters, et al, 2021). The fundamental distinction 
between consumer finance and consumer credit is conceptual, not functional. All areas of human life are profoundly influenced by education. The government of Indonesia has decided to close all academic institutions, including universities, elementary and secondary schools, and vocational schools, such as universities (Ettman, et al, 2021, llesanmi, et al, 2021, Nomura, et al, 2021, Shen, et al, 2021). The need to reduce the spread of the virus became an ultimatum, with governments across the world facing the choice of closing all schools to restrict public interaction in order to save lives, or maintaining all schools to pay the expense of those engaged in the running of the economy. The outbreak of a Coronavirus pandemic has two side consequences on the educational system. In rural regions and in urban areas, the long-term impact on families in Indonesia may be seen. A significant number of families that are less familiar in Indonesia choose to send their children to school at home.

The Asian families are already quite busy working outside the home, so it was a surprise to discover how much time they dedicate to education for their children (Cole, 2021, Du, et al, 2021, Gautam \& Gautam, 2021). Studies show that the offspring of students who regularly study face-to-face with their instructors are prone to suffer mental-health problems (Gunawan \& Argadinata, 2020). It is difficult to protect yourself against all facets of a healthy lifestyle while fighting the Coronavirus. Previous compositions have operated on a scale that has never been measured or assessed, thus these compositions cannot be compared. Severe disorder exists in disconnected, rural areas with high school-age populations due to a scarcity of information technology (Holleman, 2021, Li \& Feng, 2021). More tests have been canceled owing to the online testing technology's questionable deployment. The long-term consequences have to deal with the second point. Thousands of Indonesians will be directly impacted by this Coronavirus, and many other groups will as well. The long-term impact of education in Asia has increased equity and regional disparity (Yousaf, et al, 2021).

\subsection{Funding Efficiency of Schools}

Assess program efficiency by considering how cost-effective it is and allows the program to benefit from numerous alternatives through comparison. Then assess the next level of performance, but without a specific budget for the program. As better and bigger returns, you are more likely to benefit students by gaining new information or skills in some manner. You always have to evaluate how much work and efficiency go together. For a product's economic efficiency, effectiveness is essential because efficiency depends on how successful a product is in accomplishing particular goals relating to the additional costs (La, et al, 2021, Haroon, et al, 2021). One of the best indicators of educational efficiency and efficiency is the efficient use of education resources with good administration. Education programs must be successful, effective, and efficient to meet both supply and demand for educational resources (Lecours, et al, 2021). When educational services are dispersed as anticipated and the overall quantity of services provided is the same or higher than the original plan, education resources may be utilized effectively (Schroeder, 2021, Katz, et al, 2021). It is simpler to measure efficiency if you include money, educational activities and the outcomes of such activities (Amin \& Soomro, 2021, Arcinas, et al, Magulod Jr, 2017, Magulod Jr, 2019, Nuncio, et al, 2020, Șargu, 2021, Tolentino \& Arcinas, 2018).

\subsection{Function of Education for Economic Progress}

Where every economy plays an important role in the lives of the Asian people, let's not just because we must compete during economic globalization, but because most policies and regulations are causing considerable disharmony between the companies when running the economy that leads to a protracted economic crisis, and then in the globalization period when Macroeconomics is in operation (Barbosa, 2021). The analysis of educational activities by economic scientists, among others. The relationship between worker education and economic activity is not straightforward. On the one hand, education is a waste of public money, while on the other, education is handled by human resources for the creative potential of society. There are two views. Economic study seems to show that an economic act is (Reynolds \& McKimm, 2021, Sattari, et al, 2021). Economically sound choice of nation, money, labor, organization and limited time to meet limited human demands. Analysis of the economic 
components helps to understand the relationship between the economic system and the education system.

Macroeconomic changes impact education since many wealthy individuals now desire to be fathers of children who cannot afford to study at a higher level. Developing a dual training approach that works effectively in schools and involves collaboration with companies in the learning process is a promising trend. Macroeconomic development progress may also influence the construction of comprehensive schools financed and owned by the majority of the rich. While the school rules and programs are not the same as others, kids are expected to be favored and excellent views from all backgrounds. The training provided at the following institutions mostly generates excellent graduates who are not far away from our country's national objectives. The main goal of education is to develop an excitement for success, working skills and procedures. Accept menial tasks, since life is less fortunate and can live in any case. The macroeconomic role is useful to discuss after examining the macroeconomic function.

In line with this, the microeconomic function may be shown to enhance or diminish a person's life in direct relation to the economy. People seldom combine ups and downs with a degree of heart peace, family happiness, honesty and pureness in the often-distant world of life. Family economic circumstances often affect parents' educational status on their child's pathway. Parents intentionally or not use a reward-value strategy in their child's education plan, and it is utilized for profit and loss balancing. The concept of profit is utilized by people who decide how best they may spend money to accomplish what they desire. Economics plays a vital part in a person's life, but the explanation above points to the lack of light as a guarantee of pleasure to reach a higher economic level. There are many poor families here that can't feed and pay school bills for their children, the poorest ones mentioned above are not the economic spiritual and psychological qualities.

\section{Conclusion}

In the realm of education, economic concerns are not the central role of the holder, but actors who properly define educational achievement to conduct all training establishments and activities. The essential components are lifelong training and dedication, competency, managerial skills, and instructors in all educational facilities. The economic aim of encouraging education and teaching materials in economic processes to develop an economic person is to ensure that people have the capability and the habit of living everyday life, such as working ethics, not halfway work, productive and efficient living. Every educational institution itself seeks to maintain itself by identifying as many additional financing resources for enhancing education as feasible, and utilizing education money, it must be professional, effective and successful in the next responsibility. The cost of reeducation is increasing gradually in order to create productive human resources, the training system, the structure of the curriculum and the kind of education.

\subsection{Implications to Economics of Education}

The evaluation of the effectiveness of the education funds involves several criteria: (1) measures of the effectiveness of the issue; (b) consideration of results; and (c) quality of the education funds, between accessibility and demand for resources in education and attainment of targets without major obstacles. The accomplishment of the specified goals is effective. Effective does not stop when the aim is achieved, but until qualitative results are achieved. Management is to follow the principles of efficient finance when measures are undertaken to limit the expenses of activity within the framework of qualitative results to accomplish objectives according to the plans established. It may thus be claimed that cost efficiency is the ability to achieve financial goals and objectives as expected. 


\section{References}

1. Ahmed, M. Z., Ahmed, O., Aibao, Z., Hanbin, S., Siyu, L., \& Ahmad, A. (2020). Epidemic of COVID-19 in China and associated psychological problems. Asian journal of psychiatry, 51, 102092.

2. Alam, M. K. (2020). A systematic qualitative case study: Questions, data collection, NVivo analysis and saturation. Qualitative Research in Organizations and Management: An International Journal.

3. Al-Kindi, I., \& Al-Khanjari, Z. (2021). NVivo to Analyze the Definition of Student EBQ Qualitatively. Available at SSRN 3768217.

4. Al-Samarrai, S., Gangwar, M., \& Gala, P. (2020). The impact of the COVID-19 pandemic on education financing.

5. Amin, R. U., \& Soomro, K. A. (2021). Decentralization of Education: The Affective Role of Fiscal Decentralization in Pakistani Education System (s). FWU Journal of Social Sciences, 15(01).

6. Arcinas, M. M., Sajja, G. S., Asif, S., Gour, S., Okoronkwo, E., \& Naved, M. ROLE OF DATA MINING IN EDUCATION FOR IMPROVING STUDENTS PERFORMANCE FOR SOCIAL CHANGE. Turkish Journal of Physiotherapy and Rehabilitation, 32, 3.

7. BARBOSA, R. (2021). Essays in public economics and financial macroeconomics (Doctoral dissertation, European University Institute).

8. Bloch, E. M., Goel, R., Montemayor, C., Cohn, C., \& Tobian, A. A. (2021). Promoting access to COVID19 convalescent plasma in low-and middle-income countries. Transfusion and Apheresis Science, 60(1), 102957.

9. Cauchemez, S., Ferguson, N. M., Wachtel, C., Tegnell, A., Saour, G., Duncan, B., \& Nicoll, A. (2009). Closure of schools during an influenza pandemic. The Lancet infectious diseases, 9(8), 473-481.

10.Chang, T. Y., Hsu, M. L., Kwon, J. S., Kusdhany, M. L. S., \& Hong, G. (2021). Effect of online learning for dental education in asia during the pandemic of COVID-19. Journal of Dental Sciences.

11.Cheng, S. Y., Wang, C. J., Shen, A. C. T., \& Chang, S. C. (2020). How to safely reopen colleges and universities during COVID-19: experiences from Taiwan. Annals of internal medicine, 173(8), 638641.

12.Chevallier, J. (2021). COVID-19 outbreak and CO2 emissions: Macro-financial linkages. Journal of Risk and Financial Management, 14(1), 12.

13.Cohen, R., Delacourt, C., Gras-Le Guen, C., Launay, E., \& Society, F. P. (2020). COVID-19 and schools. Guidelines of the French Pediatric Society. Archives de Pédiatrie, 27(7), 388-392.

14.Cole, J. (2021). PL5. Training and education in Europe, Middle East, Africa, Latin America and Asia Oceania chapters, IFCN: An international survey. Clinical Neurophysiology, 132(8), e38.

15.Dalkin, S., Forster, N., Hodgson, P., Lhussier, M., \& Carr, S. M. (2021). Using computer assisted qualitative data analysis software (CAQDAS; NVivo) to assist in the complex process of realist theory generation, refinement and testing. International Journal of Social Research Methodology, 24(1), 123-134.

16.Dee, T. S., \& Murphy, M. (2021). Patterns in the Pandemic Decline of Public School Enrollment. Educational Researcher, 0013189X211034481.

17.Dereso, C. W., Srinivasan, S., \& Maheshwaran, M. (2020). Impact of COVID-19 on education and economy of Ethiopia: a rhetoric analysis. Journal of Critical Reviews, 7(19), 6876-6881.

18.Djalante, R., Nurhidayah, L., Van Minh, H., Phuong, N. T. N., Mahendradhata, Y., Trias, A., ... \& Miller, M. A. (2020). COVID-19 and ASEAN responses: Comparative policy analysis. Progress in Disaster Science, 8, 100129.

19.Du, C., Zan, M. C. H., Cho, M. J., Fenton, J. I., Hsiao, P. Y., Hsiao, R., ... \& Tucker, R. M. (2021). The Effects of Sleep Quality and Resilience on Perceived Stress, Dietary Behaviors, and Alcohol Misuse: A Mediation-Moderation Analysis of Higher Education Students from Asia, Europe and North America during the COVID-19 Pandemic. Nutrients, 13(2), 442.

20.Ettman, C. K., Abdalla, S. M., Cohen, G. H., Sampson, L., Vivier, P. M., \& Galea, S. (2021). Low assets and financial stressors associated with higher depression during COVID-19 in a nationally representative sample of US adults. J Epidemiol Community Health, 75(6), 501-508. 
21.Figueroa, J. P., Bottazzi, M. E., Hotez, P., Batista, C., Ergonul, O., Gilbert, S., ... \& Kang, G. (2021). Urgent needs of low-income and middle-income countries for COVID-19 vaccines and therapeutics. The Lancet, 397(10274), 562-564.

22.Gautam, D. K., \& Gautam, P. K. (2021). Transition to online higher education during COVID-19 pandemic: turmoil and way forward to developing country of South Asia-Nepal. Journal of Research in Innovative Teaching \& Learning.

23.Greenhawt, M., Shaker, M., Stukus, D. R., Fleischer, D. M., Hourihane, J., Tang, M. L., ... \& Mack, D. P. (2020). Managing food allergy in schools during the COVID-19 pandemic. The Journal of Allergy and Clinical Immunology: In Practice, 8(9), 2845-2850.

24.Gutiérrez-Romero, R., \& Ahamed, M. (2021). COVID-19 response needs to broaden financial inclusion to curb the rise in poverty. World Development, 138, 105229.

25.Han, E., Tan, M. M. J., Turk, E., Sridhar, D., Leung, G. M., Shibuya, K., ... \& Legido-Quigley, H. (2020). Lessons learnt from easing COVID-19 restrictions: an analysis of countries and regions in Asia Pacific and Europe. The Lancet.

26.Haroon, O., Ali, M., Khan, A., Khattak, M. A., \& Rizvi, S. A. R. (2021). Financial Market Risks during the COVID-19 Pandemic. Emerging Markets Finance and Trade, 57(8), 2407-2414.

27.Harris, A. (2020). COVID-19-school leadership in crisis?. Journal of Professional Capital and Community.

28.Holleman, M. (2021). Child Care After COVID: Equity, efficiency, and effectiveness in the financing and delivery of child care in Baltimore and Maryland.

29.Ilesanmi, F. F., llesanmi, O. S., \& Afolabi, A. A. (2021). The effects of the COVID-19 pandemic on food losses in the agricultural value chains in Africa: The Nigerian case study. Public Health in Practice, 2, 100087.

30.Inchley, J., Currie, D., Budisavljevic, S., Torsheim, T., Jåstad, A., Cosma, A., ... \& Samdal, O. (2020). Spotlight on adolescent health and well-being. Findings from the 2017/2018 Health Behaviour in School-aged Children (HBSC) survey in Europe and Canada. International report, 1.

31.Kang, Y., Baidya, A., Aaron, A., Wang, J., Chan, C., \& Wetzler, E. (2021). Differences in the Early Impact of COVID-19 on Food Security and Livelihoods and in Rural and Urban Areas in the Asia Pacific Region. Current Developments in Nutrition, 5(Supplement_2), 229-229.

32.Katz, S. E., McHenry, R., Mauer, L. G., Chappell, J. D., Stewart, L. S., Schmitz, J. E., ... \& Banerjee, R. (2021). Low in-school COVID-19 transmission and asymptomatic infection despite high community prevalence. The Journal of Pediatrics.

33.Knight, D. S., Hassairi, N., Candelaria, C. A., Sun, M., \& Plecki, M. L. (2021). Prioritizing School Finance Equity during an Economic Downturn: Recommendations for State Policy Makers. Education Finance and Policy, 1-24.

34.La, H. A., \& Miranti, R. (2021). Financial Market Responses to Government COVID-19 Pandemic Interventions: Empirical Evidence from South-East and East Asia.

35.Lecours, A., Béland, D., Fenna, A., Fenwick, T. B., Paquet, M., Rocco, P., \& Waddan, A. (2021). Explaining Intergovernmental Conflict in the COVID-19 Crisis: The United States, Canada, and Australia. Publius: The Journal of Federalism.

36.Lee, B. J., \& Yoo, M. S. (2015). Family, school, and community correlates of children's subjective well-being: An international comparative study. Child Indicators Research, 8(1), 151-175.

37.Li, X., \& Feng, L. (2021). Impact of donors' financial fairness perception on donation intention in nonprofit organizations after COVID-19 outbreak. PloS one, 16(6), e0251991.

38. Magulod Jr, G. C. (2017). Factors of school effectiveness and performance of selected public and private elementary schools: implications on educational planning in the Philippines. Asia Pacific Journal of Multidisciplinary Research, 5(1), 73-83.

39. Magulod Jr, G. C. (2019). Learning styles, study habits and academic performance of Filipino University students in applied science courses: Implications for instruction. JOTSE: Journal of Technology and Science Education, 9(2), 184-198.

40.Meanwell, E. (2021, March). Getting Started with NVivo. Indiana University Workshop in Methods. 
41.Netolicky, D. M. (2020). School leadership during a pandemic: navigating tensions. Journal of Professional Capital and Community.

42.Ng, Y. M., \& Or, P. L. P. (2020). Coronavirus disease (COVID-19) prevention: Virtual classroom education for hand hygiene.

43.Nicola, M., Alsafi, Z., Sohrabi, C., Kerwan, A., Al-Jabir, A., losifidis, C., ... \& Agha, R. (2020). The socioeconomic implications of the coronavirus pandemic (COVID-19): A review. International journal of surgery, 78, 185-193.

44.Nomura, S., Kawashima, T., Yoneoka, D., Tanoue, Y., Eguchi, A., Gilmour, S., ... \& Hashizume, M. (2021). Trends in suicide in Japan by gender during the COVID-19 pandemic, up to September 2020. Psychiatry research, 295, 113622.

45.Nuncio, R. V., Arcinas, M. M., Lucas, R. I. G., Alontaga, J. V. Q., Neri, S. G. T., \& Carpena, J. M. (2020). An E-learning outreach program for public schools: Findings and lessons learned based on a pilot program in Makati City and Cabuyao City, Laguna, Philippines. Evaluation and Program Planning, 82, 101846.

46.Rajan, S., Akhtar, N., Tripathi, A., Kumar, V., Chaturvedi, A., Mishra, P., ... \& Singh, M. (2021). Impact of COVID-19 pandemic on cancer surgery: Patient's perspective. Journal of surgical oncology, 123(5), 1188-1198.

47.Rapoport, E., Muthiah, N., Keim, S. A., \& Adesman, A. (2020). Family well-being in grandparentversus parent-headed households. Pediatrics, 146(3).

48.Reynolds, D., \& McKimm, J. (2021). Educational management and leadership in Wales: Promise, performance and potential. School Leadership \& Management, 41(1-2), 54-72.

49.Roy, D., Tripathy, S., Kar, S. K., Sharma, N., Verma, S. K., \& Kaushal, V. (2020). Study of knowledge, attitude, anxiety \& perceived mental healthcare need in Indian population during COVID-19 pandemic. Asian journal of psychiatry, 51, 102083.

50.Salahudin, S., Nurmandi, A., \& Loilatu, M. J. (2020). How to Design Qualitative Research with NVivo 12 Plus for Local Government Corruption Issues in Indonesia?. Jurnal Studi Pemerintahan, 11(3), 369-398.

51.Șargu, N. (2021). The Involvement of Management Elements in Fiscal Control Conduction. Acta Universitatis Danubius. CEconomica, 17(2).

52.Sattari, A., Khodabandehlou, R., \& Lashkari, M. (2021). Studying the process of research in management with emphasis on the concept of leadership and its implications in management and educational leadership: A bibliographic analysis. Journal of Management and Planning In Educational System, 13(2), 121-148.

53.Schroeder, T. (2021). Consider the Possibility of a COVID-19 Impact Fund. Successful Fundraising, 29(1), 4.

54.Shek, D. T. (1997). Family environment and adolescent psychological well-being, school adjustment, and problem behavior: A pioneer study in a Chinese context. The Journal of Genetic Psychology, 158(1), 113-128.

55.Shen, A. K., Hughes Iv, R., DeWald, E., Rosenbaum, S., Pisani, A., \& Orenstein, W. (2021). Ensuring Equitable Access to COVID-19 Vaccines in the US: Current System Challenges and Opportunities: Analysis examines ensuring equitable access to COVID-19 vaccines. Health Affairs, 40(1), 62-69.

56.Singh, S., Roy, M. D., Sinha, C. P. T. M. K., Parveen, C. P. T. M. S., Sharma, C. P. T. G., \& Joshi, C. P. T. G. (2020). Impact of COVID-19 and lockdown on mental health of children and adolescents: A narrative review with recommendations. Psychiatry research, 113429.

57.Syverson, E. (2021). K-12 Funding Policy Responses to COVID-19. Policy Snapshot. Education Commission of the States.

58.Tolentino, M. P., \& Arcinas, M. M. (2018). Social capital of left-behind children: Determinants and association with school performance. Asia-Pacific Social Science Review, 18(2), 16-33.

59.Tsey, K., Whiteside, M., Haswell-Elkins, M., Bainbridge, R., Cadet-James, Y., \& Wilson, A. (2010). Empowerment and Indigenous Australian health: a synthesis of findings from Family Wellbeing formative research. Health \& Social Care in the Community, 18(2), 169-179. 
60.Tsurugano, S., Nishikitani, M., Inoue, M., \& Yano, E. (2021). Impact of the COVID-19 pandemic on working students: Results from the Labour Force Survey and the student lifestyle survey. Journal of Occupational Health, 63(1), e12209.

61.Van Lancker, W., \& Parolin, Z. (2020). COVID-19, school closures, and child poverty: a social crisis in the making. The Lancet Public Health, 5(5), e243-e244.

62.Verguet, S., Hailu, A., Eregata, G. T., Memirie, S. T., Johansson, K. A., \& Norheim, O. F. (2021). Toward universal health coverage in the post-COVID-19 era. Nature Medicine, 27(3), 380-387.

63.Viner, R. M., Russell, S. J., Croker, H., Packer, J., Ward, J., Stansfield, C., ... \& Booy, R. (2020). School closure and management practices during coronavirus outbreaks including COVID-19: a rapid systematic review. The Lancet Child \& Adolescent Health, 4(5), 397-404.

64.Wang, C., Tee, M., Roy, A. E., Fardin, M. A., Srichokchatchawan, W., Habib, H. A., ... \& Kuruchittham, V. (2021). The impact of COVID-19 pandemic on physical and mental health of Asians: A study of seven middle-income countries in Asia. PloS one, 16(2), e0246824.

65.Wouters, O. J., Shadlen, K. C., Salcher-Konrad, M., Pollard, A. J., Larson, H. J., Teerawattananon, Y., \& Jit, M. (2021). Challenges in ensuring global access to COVID-19 vaccines: production, affordability, allocation, and deployment. The Lancet.

66.Yeasmin, S., Banik, R., Hossain, S., Hossain, M. N., Mahumud, R., Salma, N., \& Hossain, M. M. (2020). Impact of COVID-19 pandemic on the mental health of children in Bangladesh: A cross-sectional study. Children and youth services review, 117, 105277.

67.Yousaf, I., Bouri, E., Ali, S., \& Azoury, N. (2021). Gold against Asian Stock Markets during the COVID19 Outbreak. Journal of Risk and Financial Management, 14(4), 186.

68.Ziauddeen, N., Woods-Townsend, K., Saxena, S., Gilbert, R., \& Alwan, N. A. (2020). Schools and COVID-19: Reopening Pandora's box?. Public Health in Practice, 1, 100039. 